\title{
Stable isotopes reveal trophic segregation by sex and age in the southern giant petrel in two different food webs
}

\author{
Manuela G. Forero ${ }^{1, *}$, Jacob González-Solís ${ }^{2,3}$, Keith A. Hobson ${ }^{4,5}$, José A. Donázar ${ }^{1}$, \\ Marcelo Bertellotti ${ }^{6}$, Guillermo Blanco ${ }^{7}$, Gary R. Bortolotti ${ }^{5}$ \\ ${ }^{1}$ Department of Applied Biology, Estación Biológica de Doñana, Avenida María Luisa s/n, Pabellón del Perú, 41013 Sevilla, \\ Mallorca, Spain \\ ${ }^{2}$ Departament de Biología Animal (Vertebrats), Universitat de Barcelona, Avenida Diagonal 645, 08028 Barcelona, Spain \\ ${ }^{3}$ British Antarctic Survey, Natural Environment Research Council, High Cross, Madingley Road, Cambridge CB3 0ET, UK \\ ${ }^{4}$ Canadian Wildlife Service, 115 Perimeter Road, Saskatoon, Saskatchewan S7N 0X4, Canada \\ ${ }^{5}$ Department of Biology, University of Saskatchewan, 112 Science Place, Saskatoon SK S7N 5E2, Canada \\ ${ }^{6}$ Centro Nacional Patagónico (CONICET), Brown 3500, U9120ACV Puerto Madryn, Chubut, Argentina \\ ${ }^{7}$ Instituto de Investigación en Recursos Cinegéticos (CSIC-UCLM), Ronda de Toledo, s/n, 13005 Ciudad Real, Spain
}

\begin{abstract}
We investigated trophic ecology variation among colonies as well as sex- and age-related differences in the diet of the southern giant petrel Macronectes giganteus, a long-lived seabird that is sexually dimorphic in size. We measured stable isotopes $\left(\delta^{13} \mathrm{C}, \delta^{15} \mathrm{~N}\right)$ in blood samples collected during breeding at Bird Island (South Georgia, Antarctica) in 1998 and at 2 colonies in the Argentinean area of Patagonia in 2000 and 2001. Individuals from South Georgia showed lower $\delta^{13} \mathrm{C}$ and $\delta^{15} \mathrm{~N}$ values than those in Patagonia, as expected from the more pelagic location and the short length of the Antarctic food web. Males and females showed significant differences in the isotopic signatures at both localities. These differences agree with the sexual differences in diet found in previous studies, which showed that both sexes rely mainly on penguin and seal carrion, but females also feed extensively on marine prey, such as fish, squid and crustaceans. However, males from Patagonia showed significantly higher $\delta^{15} \mathrm{~N}$ and $\delta^{13} \mathrm{C}$ values than females did, and the reverse trend was observed at South Georgia. This opposite trend is probably related to the different trophic level of carrion between locations: whereas penguins and pinnipeds in Patagonia rely mainly on fish and cephalopods, in South Georgia they rely mainly on krill. Stable isotope values of male and female chicks in Patagonia did not differ; both attained high values, similar to adult males and higher than adult females, suggesting that parents do not provision their single offspring differently in relation to sex; however, they seem to provide offspring with a higher proportion of carrion, probably of higher quality, and more abundant food, than they consume themselves. Stable isotopes at South Georgia were not affected by age of adults. We have provided new information on intraspecific segregation in the diet in a seabird species and have also underlined the importance of considering food web structure when studying intraspecific variability in trophic ecology.
\end{abstract}

KEY WORDS: Carbon $\cdot$ Nitrogen $\cdot$ Diet $\cdot$ Interspecific variability $\cdot$ Sexual segregation $\cdot$ Macronectes giganteus Resale or republication not permitted without written consent of the publisher

\section{INTRODUCTION}

Intraspecific competition for food may play a significant role in structuring populations of animal communities. Among seabirds, there is growing evidence that food partitioning and dietary overlap influences popu- lation demographics and community structures (e.g. Ainley et al. 2003, Forero et al. 2003). Although most are interspecific approaches (e.g. Croxall et al. 1997, Hodum \& Hobson 2000, Forero et al. 2004), recent studies have provided new insights into dietary segregation within species (e.g. Gray \& Hamer 2001, Forero 
et al. 2002). Segregation in diet and foraging areas among individual seabirds from different colonies of the same species could be influenced by the differential distribution of marine resources, including prey quality and availability (Croxall \& Lishman 1987, Velando \& Freire 1999), but also by the level of intraspecific competition determined by colony and population size (Ainley et al. 2003, Forero et al. 2003). In addition, sexual segregation in feeding ecology between adult seabirds is commonly related to differences in morphology (e.g. Clarke et al. 1998, Forero et al. 2002).

Individuals may have different nutritional requirements over their life cycle (Watanuki 1992, Velando \& Freire 1999, Gray \& Harmer 2001). Growing chicks demand more energy than adult subsistence (Ricklefs et al. 1998 and references herein), and growth rate can be affected by diet type (e.g. Dahdul \& Horn 2004). Moreover, central-place foragers that provision chicks may optimize prey selection for themselves and their chicks (Ydenberg 1994, Ydenberg et al. 1994). Several studies have reported differences in size and prey type between adults, as well as in dietary changes of chicks over the nestling period (e.g. Pedrocchi et al. 1996, Forero et al. 2002, Knoff et al. 2002). Similarly, different energy demands between male and female chicks in size-dimorphic species resulted in sex-biased provisioning rates and meal size for several species (Weimerskirch et al. 2000, Daunt et al. 2001). However, to our knowledge differences in type of food delivered to male and female chicks have not been investigated, probably due to the difficulties in studying subtle differences in prey types, as well as in sexing chicks.

Potential differences in diet among age classes are not restricted to adults versus chicks. Differences in foraging proficiency between immature and adult birds may also influence the quality and quantity of food resources exploited (Porter \& Sealy 1982, Wunderle 1991). Competition for foraging habitats may also exclude younger individuals, resulting in age-related trends in use of foraging areas (Nisbet et al. 2002).

The southern giant petrel Macronectes giganteus is an important scavenger in the South Atlantic Ocean (Hunter 1985, O'Brien 1990). The restriction of its breeding distribution to sub-Antarctic and Antarctic ecosystems (Carboneres 1992, Patterson et al. in press); its conspicuous sexual size dimorphism (González-Solís et al. 2000b), which can be detected even a few days after hatching (e.g. Conroy 1972, Hunter 1984, Cooper et al. 2001), the slow growth rates of the chicks, deferred maturity and long life-span (Conroy 1972, Hunter 1984) make it an ideal model to study intraspecific trophic segregation. This species shows a noticeable sexual segregation in diet and foraging areas (Hunter 1983, Hunter \& de Brooke
1992, González-Solís et al. 2000a, Van Franeker et al. 2001, Quintana \& Dell'Arciprete 2002, Le Bohec et al. 2003, Patterson \& Fraser 2003, González-Solís \& Croxall 2005), as well as in chick-provisioning rate and meal size of chick feedings (Hunter 1983, Hunter \& Brooke 1992). However, research on intraspecific variation in diet in this and other seabird species has been limited by conventional methodologies, such as the analysis of gut contents or direct observation of birds at sea (Hobson et al. 1994). During the last decade, stable-isotope analysis (SIA) has become an increasingly popular tool to study the trophic ecology of seabirds (see review in Forero \& Hobson 2003), often complementing and extending traditional studies. This approach is based on the fact that stable-isotope ratios of nitrogen $\left({ }^{15} \mathrm{~N} /{ }^{14} \mathrm{~N}\right.$, denoted as $\left.\delta^{15} \mathrm{~N}\right)$ and carbon $\left({ }^{13} \mathrm{C} /{ }^{12} \mathrm{C}, \delta^{13} \mathrm{C}\right)$ in consumer tissues reflect those in their prey in a predictable manner (DeNiro \& Epstein 1978, 1981), thus being a good indicator of diet and trophic level. Within marine environments, more pelagic diets result in relatively lower $\delta^{13} \mathrm{C}$ values compared to benthic or inshore diets (Hobson et al. 1994, Thompson et al. 2000). The turnover rate of blood allows the study of feeding ecology during discrete periods of time (e.g. chick rearing period; Hobson \& Clark 1992).

Here, we investigated intraspecific segregation in diet and trophic habits in the southern giant petrel through $\delta^{15} \mathrm{~N}$ and $\delta^{13} \mathrm{C}$ analyses. Our main objectives were to (1) study the reported sexual segregation in diet and foraging habits of adults in this species at 2 separated breeding locations, north and south of the Antarctic Polar Front (Fig. 1) (Hunter 1983, GonzálezSolís et al. 2000a), by using the SIA approach; (2) test if the reported differences in the provisioning rate and meal size between male and female chicks is also accompanied by a differential provisioning in food type; and (3) investigate the intraspecific variation of the diet with age, both between chicks and adults, as well as over the adult lifespan of a particularly longlived species.

\section{MATERIALS AND METHODS}

Species and study sites. The breeding range of the southern giant petrel Macronectes giganteus extends from $67^{\circ} \mathrm{S}$ on the Antarctic continent, the Falkland Islands and north to the Argentinean area of Patagonia (Carboneres 1992, Patterson et al. in press). Males are 20 to $35 \%$ heavier and 5 to $15 \%$ larger in several linear measurements than females (Hunter 1987, GonzálezSolís et al. 2000a). This species breeds during the austral summer, from October to April, with an incubation and fledging period than spans 2 and $4 \mathrm{mo}$, respectively (Hunter 1987). Our studied colonies were 
located on 2 islands off the northern Patagonia coast of Argentina and on 1 island north of the South Georgia archipelago, north and south of the Antarctic Polar Front, respectively (Fig. 1). The 2 colonies in Patagonia are located at Arce Island $\left(45^{\circ} 00^{\prime} \mathrm{S}, 65^{\circ} 29^{\prime} \mathrm{W}\right.$, about 500 breeding pairs) and Gran Robredo Island ( $45^{\circ} 08^{\prime} \mathrm{S}, 66^{\circ} 03^{\prime} \mathrm{W}$, about 1700 breeding pairs) (Yorio et al. 1998), 7 and $14 \mathrm{~km}$ off the coast and $47 \mathrm{~km}$ apart. Pinnipeds and other seabirds, such as penguins, cormorants, gulls and skuas, are also common breeders on both islands (Yorio et al. 1998). The study site at South Georgia was on Bird Island (54 $03^{\prime} \mathrm{S}, 38^{\circ} 36^{\prime} \mathrm{W}$, subAntarctic Atlantic Ocean, 500 to 600 breeding pairs), about $2200 \mathrm{~km}$ apart from the northern Patagonia colonies. South Georgia is an important breeding site for many top predators, including several albatrosses, penguins and pinniped species, which often forage in Patagonian waters (Croxall \& Wood 2002).

Sampling and stable isotope analysis. Blood sampling in Patagonia was carried out in December 1999 (breeding season 1999 to 2000) on Arce Island and in January 2001 (breeding season 2000 to 2001) on Arce and Gran Robredo Islands. Blood samples from individuals breeding at South Georgia were taken in November 1998 (breeding season 1998 to 1999). Thus, all adults were sampled during the end of the incubation or early chick-rearing periods (chicks about $20 \mathrm{~d}$ old). We caught adults and chicks on their nests, took about $0.3 \mathrm{ml}$ of whole blood from the foot vein, and transferred it to 2 different vials containing $1.5 \mathrm{ml}$ of $70 \%$ ethanol (Hobson et al. 1997). Blood was stored at 20 to $25^{\circ} \mathrm{C}$ until analysis of stable isotopes or molecular sexing (Ellegren 1996). At South Georgia the age of some birds was known because they were banded as chicks.

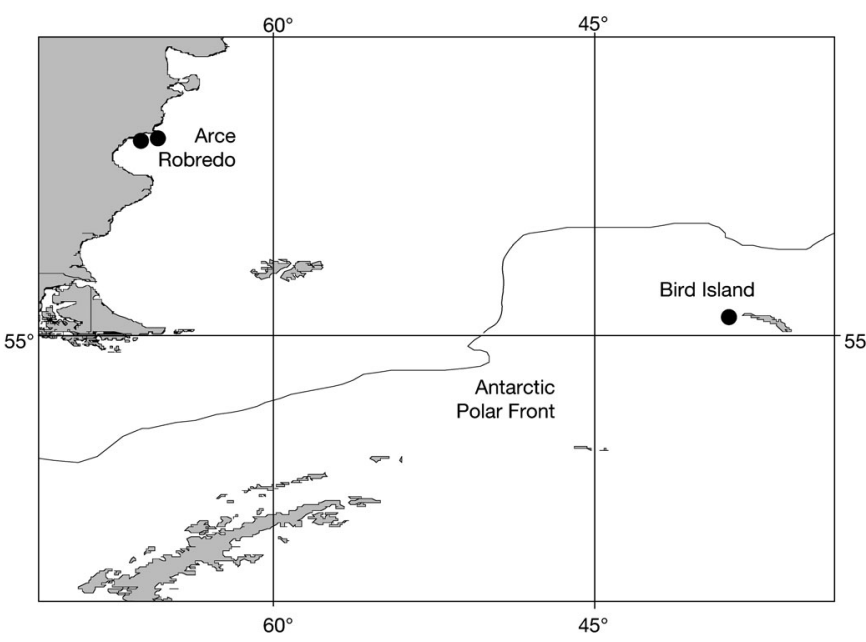

Fig. 1. Study area in the Southern Ocean. Colony sites from Patagonia (left) and South Georgia (right) are indicated. Note the position of the Antarctic Polar Front (according to Orsi et al. 1995)
After preparation of samples (see Hobson et al. 1997 for details), stable carbon and nitrogen isotope assays were performed on $1 \mathrm{mg}$ sub-samples of homogenized materials by loading into tin cups and combusting in a Europa ANCA-GST elemental analyzer (Europa Scientific). Resultant $\mathrm{CO}_{2}$ and $\mathrm{N}_{2}$ gases were then analyzed using an interfaced Europa 20:20 continuousflow isotope ratio mass spectrometer (CFIRMS, Europa Scientific), with every 5 unknowns separated by 2 laboratory standards (egg albumen). Stable isotope abundance was expressed in standard $\delta$ notation relative to carbonate Pee Dee Belemnite and atmospheric nitrogen. Based on hundreds of measurements of organic standards (albumen and collagen), the analytical precision $( \pm 1 \mathrm{SD})$ of these measurements was estimated to be \pm 0.1 and $\pm 0.3 \%$ for carbon and nitrogen, respectively.

\section{RESULTS}

The only colony of Macronectes giganteus sampled during 2 consecutive breeding seasons was Arce Island (see 'Materials and methods') in Patagonia, so we compared $\delta^{15} \mathrm{~N}$ and $\delta^{13} \mathrm{C}$ values between breeding seasons for adults in this colony controlling for sex. There were no significant differences between seasons for males or females of this colony in either $\delta^{15} \mathrm{~N}$ (2-way ANOVA-season: $F_{1,16}=0.49, \mathrm{p}=0.50$; sex: $F_{1,16}=$ $5.78, \mathrm{p}=0.03$; season $\times$ sex: $\left.F_{1,16}=0.59, \mathrm{p}=0.46\right)$ or $\delta^{13} \mathrm{C}$ values (season: $F_{1,16}=0.95, \mathrm{p}=0.35$; sex: $F_{1,16}=$ $3.37, \mathrm{p}=0.09$; season $\times$ sex: $\left.F_{1,16}=3.85, \mathrm{p}=0.07\right)$. We therefore pooled data from both seasons in subsequent analyses.

Regarding differences in isotope values among the 3 studied colonies and sex of adult birds, we found a significant effect of colony on $\delta^{15} \mathrm{~N}$ and $\delta^{13} \mathrm{C}$ values of adult birds, as well as a significant interaction between colony and sex (2-way ANOVA $-\delta^{15} \mathrm{~N}$, colony: $F_{2,59}=511.83, \mathrm{p}<0.001 ;$ sex: $F_{1,59}=0.25, \mathrm{p}=0.60 ;$ colony $\times$ sex: $F_{2,59}=10.2, \mathrm{p}<0.001 ; \delta^{13} \mathrm{C}$, colony: $F_{2,59}=$ $329.61, \mathrm{p}<0.001$; sex: $F_{1,59}=0.40, \mathrm{p}=0.53$; colony $\times$ sex: $\left.F_{2,59}=15.57, \mathrm{p}<0.001\right)$. Post-hoc Tukey comparisons suggested that differences between colonies in both carbon and nitrogen isotopes lie between South Georgia and the 2 colonies in Patagonian (all $\mathrm{p}<0.001)$. Individuals from South Georgia showed lower $\delta^{15} \mathrm{~N}$ and $\delta^{13} \mathrm{C}$ values than individuals from Arce and Gran Robredo Islands. Values of $\delta^{15} \mathrm{~N}$ and $\delta^{13} \mathrm{C}$ did not differ between the 2 Patagonian colonies (Tukey's tests, all $\mathrm{p}>0.60$ ). However, in the Patagonian colonies males showed higher $\delta^{15} \mathrm{~N}$ and $\delta^{13} \mathrm{C}$ values than females (Fig. 2). In contrast, as indicated by the significant interaction of colony and sex (see above), adults from South Georgia showed the opposite trend, 


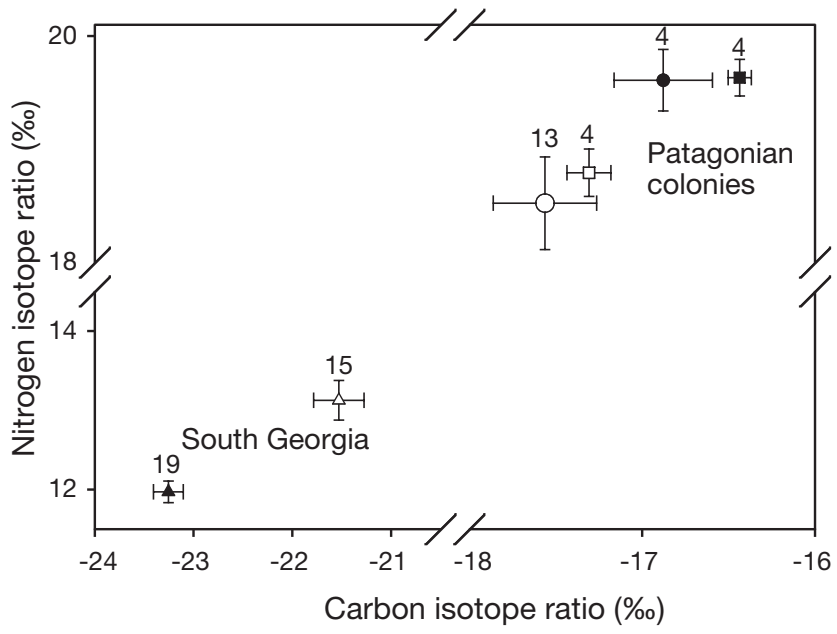

Fig. 2. Macronectes giganteus. Mean $\delta^{15} \mathrm{~N}$ and $\delta^{13} \mathrm{C}( \pm \mathrm{SE})$ values and sample sizes of adult southern giant petrel males (filled symbols) and females (empty symbols) at Bird Island (triangles) and Patagonian colonies (Arce Island represented by circles and Gran Robredo Island by squares). Individuals from the 2 Patagonian colonies were considered together in the analyses

with males having lower $\delta^{15} \mathrm{~N}$ and $\delta^{13} \mathrm{C}$ values than females. Differences between males and females in $\delta^{15} \mathrm{~N}$ and $\delta^{13} \mathrm{C}$ values were larger in the South Georgia colony (Fig. 2).

In the Patagonian colonies there were no significant differences between male and female chicks in either $\delta^{15} \mathrm{~N}\left(2\right.$-way ANOVA- chick sex: $F_{1,21}=0.04$, $\mathrm{p}=0.85$; colony: $F_{1,21}=1.47, \mathrm{p}=0.24$; chick sex $\times$ colony: $F_{1,21}=0.46, \mathrm{p}=0.51$ ) or $\delta^{13} \mathrm{C}$ values (sex: $F_{1,21}=0.61, \mathrm{p}=0.45$; colony: $F_{1,21}=0.09, \mathrm{p}=0.77$; colony $\times$ sex: $\left.F_{1,21}=0.05, p=0.82\right)$. The lack of significance of both the colony effect and its interaction with sex indicated that male and female chicks showed similar stable-isotope values at Arce and Gran Robredo Islands. Female and male chicks were then pooled for further analyses.

Since isotope values of adults differed between sexes (see above, Fig. 2), we used a fixed factor with 3 levels: adult males, adult females and chicks. The combined effect of this factor was significant and consistent in both Patagonian colonies for $\delta^{15} \mathrm{~N}$ (2-way ANOVA - colony: $F_{1,49}=0.15, \mathrm{p}=0.70$; chicks-adults: $F_{2,49}=13.69, \mathrm{p}<0.001$; colony $\times$ chicks-adults: $F_{2,49}=$ $0.18, \mathrm{p}=0.47$ ) and $\delta^{13} \mathrm{C}$ values (colony: $F_{2,49}=1.52, \mathrm{p}=$ 0.22 ; chicks-adults: $F_{2,49}=10.71, \mathrm{p}<0.001$; colony $\times$ chicks-adults: $\left.F_{2,49}=1.45, \mathrm{p}=0.25\right)$. Post-hoc tests showed that differences between age classes were due to the levels of $\delta^{15} \mathrm{~N}$ and $\delta^{13} \mathrm{C}$ being lower in adult females than in both adult males and chicks (Tukey's test, all $\mathrm{p}<0.003)$, which exhibited similar values of both isotopes (Tukey's test, all p > 0.433) (Fig. 3).

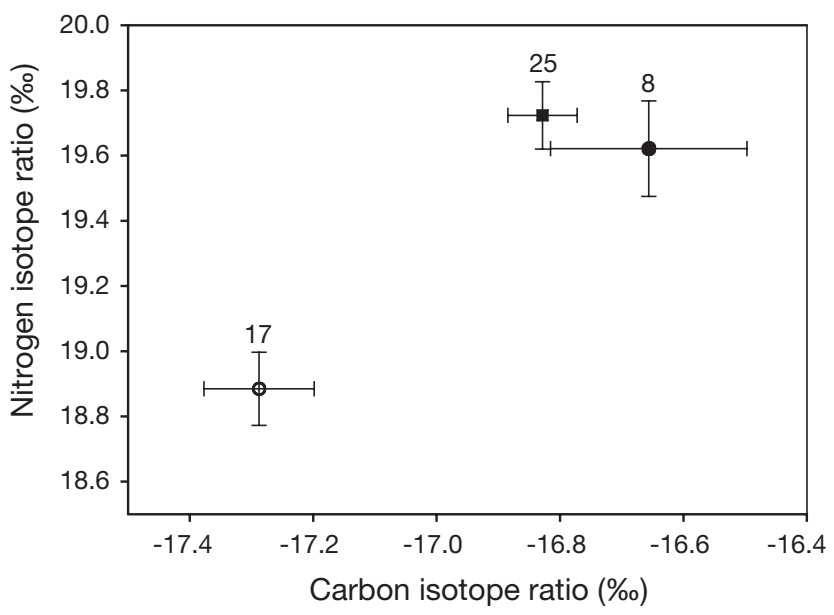

Fig. 3. Macronectes giganteus. Mean $\delta^{15} \mathrm{~N}$ and $\delta^{13} \mathrm{C}( \pm \mathrm{SE})$ and sample sizes of adult southern giant petrel males $(\bullet)$, females $(\mathrm{O})$ and chicks (घ) at the Patagonian colonies. Individuals from Arce and Gran Robredo Islands have been pooled as we did not find significant differences among colonies (see 'Results')

For individuals from South Georgia we investigated possible age effects among adult birds. For those individuals that were banded as chicks we knew their exact age (range: 10 to $37 \mathrm{yr}, \mathrm{n}=28$ ). We found no significant correlation between isotopic values and age in either females (Pearson correlation $-\delta^{15} \mathrm{~N}$ : $\mathrm{r}=-0.33$, $\left.\mathrm{n}=17, \mathrm{p}=0.20 ; \delta^{13} \mathrm{C}: \mathrm{r}=-0.28, \mathrm{n}=17, \mathrm{p}=0.28\right)$ or males $\left(\delta^{15} \mathrm{~N}: \mathrm{r}=0.24, \mathrm{n}=11, \mathrm{p}=0.47 ; \delta^{13} \mathrm{C}: \mathrm{r}=0.06\right.$, $\mathrm{n}=11, \mathrm{p}=0.88$ ).

\section{DISCUSSION}

Dietary segregation in the southern giant petrel Macronectes giganteus measured by stable isotopes was noticeable with respect to sex, as well as between chicks and adults. We found no differences in the diet between male and female chicks, nor any variation with age of adults from 10 to $37 \mathrm{yr}$ old. Individuals from South Georgia showed lower $\delta^{13} \mathrm{C}$ and $\delta^{15} \mathrm{~N}$ values than those breeding at the Patagonian colonies. Several factors can contribute to create such differences. It is known that marine birds and mammals from northtemperate and Arctic oceans have higher $\delta^{15} \mathrm{~N}$ values than those from south-temperate and Antarctic oceans (Kelly 2000), small-scale latitudinal gradients have not been described in southern oceans for this isotope (but see Jennins \& Warr 2003 for the North Sea) and could also contribute to the lower $\delta^{15} \mathrm{~N}$ values in South Georgia than in Patagonia. However, a general latitudinal decline in $\delta^{13} \mathrm{C}$ has been documented in the marine plankton of southern oceans, and similar differences might exist in birds (Sackett et al. 1965, Rau et al. 1982, 
Goericke et al. 1994). Secondly, the more positive $\delta^{13} \mathrm{C}$ values from Patagonia could be a result of those birds foraging at shorter distances and in a more neritic environment compared to those from South Georgia (Orgeira 2001, Quintana \& Dell'Arciprete 2002). Patagonian colonies are located relatively close to the mainland coast (with a very wide continental shelf [Fig. 1] where neritic fronts are abundant; Acha et al. 2004). In contrast, South Georgia is located in a more pelagic environment, far from any other mainland area and surrounded by a narrow continental shelf. Moreover, the mean distance traveled to the feeding areas of the Patagonian birds is about $30 \%$ less than that covered by birds from South Georgia.

Finally, differences in the length of food chains between Patagonian and Antarctic ecosystems probably also contributed to the important deviations in $\delta^{15} \mathrm{~N}$ values between the 2 areas. In both northern and southern colonies giant petrels probably feed mainly on penguin and pinniped carrion to a similar extent; however, this resource occupied different trophic levels in Patagonia and Antarctica (Rau et al. 1992, Forero et al. 2004). The Antarctic ecosystem food web is short, and most organisms, including macaroni (Eudyptes chrysolophus) and gentoo (Pygoscelis papua) penguins, as well as Antarctic fur seals Arctocephalus gazella, rely heavily upon krill, which shows comparatively low $\delta^{15} \mathrm{~N}$ and $\delta^{13} \mathrm{C}$ values (Rau et al. 1992, Reid \& Arnould 1996, Croxall et al. 1997, Hodum \& Hobson 2000). In contrast, anchovy Engraulis anchoita constitutes the main food of penguins in Patagonia (Forero et al. 2002), with greater isotopic values than Antarctic krill (2.3 vs. 3.3; Sanger 1987, Hodum \& Hobson 2000, Forero et al. 2004). Similarly, southern sea lions Otaria flavescens from Patagonia feed mainly on cephalopod and fish species (Alonso et al. 2000). Consequently, isotopic signatures of giant petrels feeding around South Georgia are expected to be relatively lower than those feeding in the neighboring Patagonian waters.

Sexual segregation in diet and foraging ecology has been reported previously for both southern and northern giant petrels (Macronectes halli) in South Georgia and it has been related to the larger size of males compred to females (Hunter 1983, González-Solís et al. 2000a,b). Similar sexual differences in foraging ecology of southern giant petrels from Patagonia have also been found (F. Quintana \& O. P. Dell'Arciprete unpubl.). During the breeding season, males forage mainly in coastal habitats and rely almost exclusively on penguin and pinniped carrion. Carrion is also the most important resource for females, but they also feed extensively on marine prey, such as fish, squid and krill, and show more pelagic habits than males. In the present study, at both South Georgia and the Patagonian colonies, we found differences in the isotopic signatures between males and females, confirming that they exploited different food resources. However, sexual segregation in stable isotope values at each locality showed opposite trends. At South Georgia, males appeared to consume a higher proportion of lower trophic level prey than females (Fig. 2). The same segregation in isotopic values has been found for northern giant petrels at this locality (González-Solís \& Croxall 2005). In contrast, southern giant petrel males from Patagonia showed higher $\delta^{15} \mathrm{~N}$ and $\mathrm{d}^{13} \mathrm{C}$ values than females. This opposite trend in sexual segregation does not necessarily mean that males and females have reversed ecological niches in South Georgia and Patagonia. The most parsimonious interpretation is that the main food of males, namely penguin and pinniped carrion, occupies a contrasting trophic level in each locality, as commented on above. At South Georgia, a further reason for the higher isotopic values of females may be that they often visit waters above the Antarctic polar front for feeding, with a consequent increase in isotopic signatures, whereas the foraging areas of males are more restricted to the Antarctic waters around South Georgia (González-Solis et al. 2000a).

In concordance with other studies on seabird diet applying SIA (e.g. Hodum \& Hobson 2000, Forero et al. 2002), southern giant petrel chicks at Patagonian colonies occupied higher trophic positions than their parents. However, this difference was largely a matter of the lower $\delta^{15} \mathrm{~N}$ and $\delta^{13} \mathrm{C}$ values of adult females. It has been suggested that the production of stomach oil in some seabirds may result in isotopic differences between chicks and adults (Thompson et al. 2000). However, other factors may also contribute to the differences in the isotopic composition between them, such as a differential selection of food for the provisioning chicks, as well as differences between the male and female provisioning rates of chicks. For instance, some studies have shown that males provision food to chicks more frequently and probably with larger meal size than females do (Hunter 1983, Hunter \& Brooke 1992, González-Solís et al. 2000b). In our study area, where penguin and pinniped carrion was available near both colonies during the study period, food may have been readily located by males, thus allowing them to feed chicks more frequently than females could. As a result, the isotopic signatures of males and chicks would be more similar compared to those of females. Relatively high isotopic values in chicks could also be related to the selection of carrion for chick provisioning, since this type of food is a more complete source of nutrients than invertebrates, fish or squid (Watanuki 1992). Indeed, as male chicks receive more food than female chicks and take longer to fledge due to the noticeable sexual size dimorphism in southern giant petrels (Hunter 1983, Hunter \& Brooke 
1992), parents might provision the sexes with different food. Although we found no evidence of this, differences in the type of food delivered to male and female chicks cannot be completely excluded, since our sampling was carried out only during the early chick-rearing period.

We found no significant correlation between $\delta^{15} \mathrm{~N}$ and $\delta^{13} \mathrm{C}$ values and adult age. Although these results suggest that food exploitation does not improve with age, we cannot discount a possibility of some age effects. As the youngest individual in our sample was $10 \mathrm{yr}$ old (age of first breeding between 4 and $10 \mathrm{yr}$ old; Conroy 1972, Hunter 1984), age-related differences in diet and foraging ecology may be limited to younger ages.

We have confirmed intraspecific patterns of food partitioning in the southern giant petrel between sexes and age classes. Application of SIA to the study has also revealed a striking reverse trend in the sexual segregation of the isotopic composition between the Patagonian and South Georgian colonies. Thus, further isotopic and conventional studies that compare seabird diets and trophic partitioning among disparate sites with different trophic structure and food web length are needed, both at the level of individual species and communities (e.g. Forero et al. 2004).

Acknowledgements. We thank the Fundación Patagonia Natural staff of the Patagonian Natural Reserves and Jorge Owens for logistic and field support and the Dirección Nacional de Flora y Fauna of Argentina and government offices of Chubut province for facilitating permits and the field team at Bird Island as well as the British Antarctic Survey staff, especially John Croxall, Dirk Briggs and Janet Silk, for invaluable support and advice on many occasions. J. Juste improved the manuscript. D. Harris performed the stable isotope ratio analysis in the Laboratory of Soil Science, University of California, Davis. P. Healy assisted with sample preparation. During field work, M.G.F. was supported by a postdoctoral grant from the Ministerio de Educación y Ciencia of Spain and J.G.-S. by a Marie Curie grant from the European Union. During writing M.G.F. and J.G.-S. were supported by a contract of the Program Ramón y Cajal of the Ministerio de Ciencia y Tecnología (MCyT) of Spain and by Fondos FEDER. Additional financial support was provided by the project REN2002-00450/GLO from MCyT, an NSERC grant to G.R.B. and a Canadian Wildlife Service grant to K.A.H.

\section{LITERATURE CITED}

Acha EM, Mianzan HW, Guerrero RA, Favero M, Bava J (2004) Marine fronts at the continental shelves of austral South America: physical and ecological processes. J Mar Syst 44:83-105

Ainley DG, Ford RG, Brown ED, Suryan RM, Irons DB (2003) Prey resources, competition, and geographic structure of kittiwake colonies in Prince William Sound. Ecology 84: 709-723

Alonso MA, Crespo EA, Pedraza SN, Garcia NA, Coscarella MA (2000) Food habits of the South American sea lion, Otaria flavescens, off Patagonia, Argentina. Fish Bull (Wash DC) 98:250-283
Carboneres C (1992) Order Procellariiformes. In: Del Hoyo J, Eliot A, Sargatal J (eds) Handbook of the birds of the world. Lynx Editions, Barcelona, p 198-272

Clarke JR, Manly B, Kerry K, Gardner H, Franchi E, Corsolini S, Focardi S (1998) Sex differences in Adélie penguin foraging strategies. Polar Biol 20:248-258

Conroy JWH (1972) Ecological aspects of the biology of the giant petrel Macronectes giganteus (Gmelin) in the maritime Antarctic. Sci Rep Br Antarct Surv 75:1-74

Cooper J, Brooke ML, Burger AE, Crawford RJM, Hunter S, Williams T (2001) Aspects of the breeding biology of the northern giant petrel (Macronectes halli) and the southern giant petrel (M. giganteus) at sub-Antarctic Marion Island. Int J Ornithol 4:53-68

Croxall JP, Lishman GS (1987) The food and feeding ecology of penguins. In: Croxall JP (ed) Seabirds: feeding ecology and role in marine ecosystems. Cambridge University Press, Cambridge, p 101-134

Croxall JP, Wood AG (2002) The importance of the Patagonian shelf for top predator species breeding at South Georgia. Aquat Conserv Mar Freshw Ecosyst 12:101-118

Croxall JP, Prince PA, Reid K (1997) Dietary segregation of krill-eating South Georgia seabirds. J Zool Lond 242: 531-556

Dahdul WM, Horn MH (2004) Energy allocation and postnatal growth in captive elegant tern (Sterna elegans) chicks: responses to high- versus low-energy diets. Auk 120:1069-1081

Daunt F, Monaghan P, Wanless S, Harris MP, Griffiths R (2001) Sons and daughters: age-specific differences in parental rearing capacities. Funct Ecol 15:211-216

DeNiro MJ, Epstein S (1978) Influence of diet on the distribution of carbon isotopes in animals. Geochim Cosmochim Acta 42:495-506

DeNiro MJ, Epstein S (1981) Influence of diet on the distribution of nitrogen isotopes in animals. Geochim Cosmochim Acta 45:341-351

Ellegren H (1996) First gene on the avian W chromosome (CHD) provides a tag for universal sexing of non-ratite birds. Proc R Soc Lond B 263:1635-1641

Forero MG, Hobson KA (2003) Using stable isotopes of nitrogen and carbon to study seabird ecology: applications in the Mediterranean seabird community. Sci Mar 67:23-32

Forero MG, Hobson KA, Bortolotti GR, Donázar JA, Bertellotti M, Blanco G (2002) Food resource utilisation by the Magellanic penguin evaluated through stable-isotope analysis: segregation by sex and age and influence on offspring quality. Mar Ecol Prog Ser 234:289-299

Forero MG, Tella JL, Hobson KA, Bertellotti M, Blanco G (2003) Conspecific food competition explains variability in colony size: a test in Magellanic penguins. Ecology 83: $3466-3475$

Forero MG, Bortolotti GR, Hobson KA, Donázar JA, Bertellotti M, Blanco G (2004) High trophic overlap within the seabird community of Argentinean Patagonia: a multiscale approach. J Anim Ecol 73:789-801

Goericke R, Montoya JP, Fry B (1994) Physiology of isotopic fractionation in algae and cyanobacteria. In: Lajtha $\mathrm{K}$, Michener RH (eds) Stable isotopes in ecology and environmental science. Blackwell Scientific, London, p 187-221

González-Solís J, Croxall JP (2005) Differences in foraging behaviour and feeding ecology in giant petrels. In: Ruckstuhl KE, Neuhaus P (eds) Sexual segregation in vertebrates: ecology of the two sexes. Cambridge University Press, Cambridge, p 92-111

González-Solís J, Croxall JP, Wood AG (2000a) Foraging partitioning between giant petrels Macronectes spp. and its 
relationship with breeding population changes at Bird Island, South Georgia. Mar Ecol Prog Ser 204:279-388 González-Solís J, Croxall JP, Wood AG (2000b) Sexual dimorphism and sexual segregation in foraging strategies of northern giant petrels Macronectes halli during incubation. Oikos 90:390-398

Gray CM, Hamer KC (2001) Food-provisioning behaviour of male and female Manx shearwaters, Puffinus puffinus. Anim Behav 62:117-121

Hobson KA, Clark RG (1992) Assessing avian diets using stable isotopes. II. Factors influencing diet-tissue fractionation. Condor 94:189-197

Hobson KA, Piatt JF, Pitocchelli J (1994) Using stable isotopes to determine seabird trophic relationships. J Anim Ecol 63: 786-798

Hobson KA, Gibbs HL, Gloutney ML (1997) Preservation of blood and tissue samples for stable-carbon and stablenitrogen isotope analysis. Can J Zool 75:1720-1723

Hodum PJ, Hobson KA (2000) Trophic relationships among Antarctic fulmarine petrels: insights into dietary overlap and chick provisioning strategies inferred from stableisotope $\left(\delta^{15} \mathrm{~N}\right.$ and $\left.\delta^{13} \mathrm{C}\right)$ analyses. Mar Ecol Prog Ser 198: $273-281$

Hunter S (1983) The food and feeding of the giant petrels Macronectes halli and M. giganteus at South Georgia. J Zool Lond 200:521-538

Hunter S (1984) Breeding biology and population dynamics of giant petrels Macronectes at South Georgia (Aves: Procellariiformes). J Zool Lond 203:441-460

Hunter S (1985) The role of giant petrels in the Southern Ocean ecosystem. In: Siegfried WR, Laws RM, Condy PR (eds) Antarctic nutrient cycles and food webs. SpringerVerlag, Berlin, p 534-542

Hunter S (1987) Species and sexual isolation mechanisms in sibling species of giant petrels Macronectes. Polar Biol 7: 295-301

Hunter S, de Brooke M (1992) The diet of giant petrels Macronectes spp. at Marion Island, Southern Indian Ocean. Colon Waterbirds 15:56-65

Jennins S, Warr KJ (2003) Environmental correlates of largescale spatial variation in the ${ }^{15} \mathrm{~N}$ of marine animals. Mar Biol 142:1131-1140

Kelly JF (2000) Stable isotopes of carbon and nitrogen in the study of avian and mammalian trophic ecology. Can J Zool 78:1-27

Knoff AJ, Macko SA, Edwin RM, Brown KM (2002) Stable isotope analysis of temporal variation in the diets of pre-fledged laughing gulls. Colon Waterbirds 25:142-148

Le Bohec C, Gauthier-Clerc M, Gendner JP, Chatelain N, Le Maho Y (2003) Nocturnal predation of king penguins by giant petrels on the Crozet Islands. Polar Biol 26:587-590

Nisbet ICT, Montoya JP, Burger J, Hatch JJ (2002) Use of stable isotopes to investigate individual differences in diets and mercury exposures among common terns Sterna hirundo in breeding and wintering grounds. Mar Ecol Prog Ser 242:267-274

O'Brien RM (1990) Southern giant petrel Macronectes giganteus. In: Marchant S, Higgins PJ (eds) Handbook of the Australian, New Zealand \& Antarctic birds. Oxford University Press, Melbourne, p 356-369

Orgeira JL (2001) Distribución espacial de densidades de aves marinas en la plataforma continental argentina y Océano Atlántico Sur. Ornitol Neotropical 12:45-55

Orsi AH, Whitworth T, Nowlin WD (1995) On the meridional extent and fronts of the Antarctic circumpolar current. Deep-Sea Res I 42:641-673

Patterson DL, Fraser WR (2003) Satellite tracking southern giant petrels at Palmer station, Antarctica. Feature articles, Vol 8, Microwave Telemetry, available at: www. microwavetelemetry.com/newsletters.php, p 3-4

Patterson DL, Woehler EJ, Croxall JP, Cooper J, Poncet S, Fraser WR (in press) Breeding distribution and population status of the northern giant petrel (Macronectes halli) and southern giant petrel (Macronectes giganteus). Mar Ornithol

Pedrocchi V, Oro D, González-Solís J (1996) Differences between diet of adult and chick Audouin's gulls Larus audouinii at the Chafarinas Islands, SW Mediterranean. Ornis Fenn 73:124-130

Porter JM, Sealy SG (1982) Dynamics of seabirds multispecies feeding flocks: age-related feeding behaviour. Behaviour 81:91-109

Quintana F, Dell'Arciprete OP (2002) Foraging grounds of southern giant petrels (Macronectes giganteus) on the Patagonian shelf. Polar Biol 25:159-161

Rau GH, Sweeney RE, Kaplan IR (1982) Plankton ${ }^{13} \mathrm{C}:{ }^{12} \mathrm{C}$ ratio changes with latitude: differences between northern and southern oceans. Deep-Sea Res 29:1035-1039

Rau GH, Ainley DG, Bengtson JL, Torre JJ, Hopkins TL (1992) ${ }^{15} \mathrm{~N} /{ }^{14} \mathrm{~N}$ and ${ }^{13} \mathrm{C} /{ }^{12} \mathrm{C}$ in Weddell Sea birds, seals, and fish: implications for diet and trophic structure. Mar Ecol Prog Ser 84:1-8

Reid K, Arnould JPY (1996) The diet of Antarctic fur seals Arctocephalus gazella during the breeding season at South Georgia. Polar Biol 16:105-114

Ricklefs RE, Starck JM, Konarzewski M (1998) Internal constraints on growth in birds. In: Starck JM, Ricklefs RE (eds) Avian growth and development. Oxford University Press, Oxford, p 266-287

Sackett WM, Eckelmann WR, Bender ML, Bé AWH (1965) Temperature dependence of carbon isotope composition in marine plankton and sediments. Science 148:235-237

Sanger GA (1987) Trophic levels and trophic relationships of seabirds in the Gulf of Alaska. In: Croxall JP (ed) Seabirds: feeding ecology and role in marine ecosystems. Cambridge University Press, Cambridge, p 229-257

Thompson DR, Phillips RA, Stewart FM, Waldron S (2000) Low $\delta^{13} \mathrm{C}$ signatures in pelagic seabirds: lipid ingestion as a potential source of ${ }^{13} \mathrm{C}$-depleted carbon in the Procellariiformes. Mar Ecol Prog Ser 208:265-271

Van Franeker J, Creuwels JCS, Van der Veer W, Cleland S, Robertson G (2001) Unexpected effects of climate change on the predation of Antarctic petrels. Antarct Sci 13: 430-439

Velando A, Freire J (1999) Intercolony and seasonal differences in the breeding diet of European shags on the Galician coast (NW Spain). Mar Ecol Prog Ser 188:225-236

Watanuki Y (1992) Individual diet difference, parental care and reproductive success in slaty-baked gulls. Condor 94: 159-171

Weimerskirch H, Barbraud C, Lys P (2000) Sex differences in parental investment and chick growth in wandering albatrosses: fitness consequences. Ecology 81:309-318

Wunderle JM (1991) Age-specific foraging proficiency in birds. Curr Ornithol 7:273-324

Ydenberg RC (1994) The behavioural ecology of provisioning in birds. Ecoscience 1:1-14

Ydenberg RC, Welham CVJ, Schmid-Hempel R, SchmidHempel P, Beauchamp G (1994) Time and energy constraints and the relationships between currencies in foraging theory. Behav Ecol 5:28-34

Yorio P, Frere, E, Gandini P, Harris G (1998) Atlas de la distribución reproductiva de aves marinas en el litoral patagónico Argentino. Fundación Patagonia Natural, Chubut 